January 2005 - NREL/CP-500-37355

\title{
Ride-Through Capability Predictions for Wind Power Plants in the ERCOT Network
}

\section{Preprint}

E. Muljadi and C.P. Butterfield National Renewable Energy Laboratory

J. Conto and K. Donohoo Electric Reliability Council of Texas

To be presented at the 2005 IEEE Power Engineering Society General Meeting San Francisco, California June 12-16, 2005

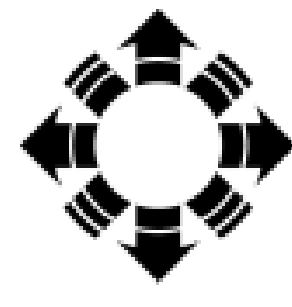

\section{NPEI}

National Renewable Energy Laboratory 1617 Cole Boulevard, Golden, Colorado 80401-3393 303-275-3000 • www.nrel.gov

Operated for the U.S. Department of Energy

Office of Energy Efficiency and Renewable Energy

by Midwest Research Institute $\bullet$ Battelle 


\section{NOTICE}

The submitted manuscript has been offered by an employee of the Midwest Research Institute (MRI), a contractor of the US Government under Contract No. DE-AC36-99G010337. Accordingly, the US Government and MRI retain a nonexclusive royalty-free license to publish or reproduce the published form of this contribution, or allow others to do so, for US Government purposes.

This report was prepared as an account of work sponsored by an agency of the United States government. Neither the United States government nor any agency thereof, nor any of their employees, makes any warranty, express or implied, or assumes any legal liability or responsibility for the accuracy, completeness, or usefulness of any information, apparatus, product, or process disclosed, or represents that its use would not infringe privately owned rights. Reference herein to any specific commercial product, process, or service by trade name, trademark, manufacturer, or otherwise does not necessarily constitute or imply its endorsement, recommendation, or favoring by the United States government or any agency thereof. The views and opinions of authors expressed herein do not necessarily state or reflect those of the United States government or any agency thereof.

Available electronically at http://www.osti.gov/bridge

Available for a processing fee to U.S. Department of Energy and its contractors, in paper, from:

U.S. Department of Energy

Office of Scientific and Technical Information

P.O. Box 62

Oak Ridge, TN 37831-0062

phone: 865.576 .8401

fax: 865.576 .5728

email: mailto:reports@adonis.osti.gov

Available for sale to the public, in paper, from:

U.S. Department of Commerce

National Technical Information Service

5285 Port Royal Road

Springfield, VA 22161

phone: 800.553 .6847

fax: 703.605.6900

email: orders@ntis.fedworld.gov

online ordering: http://www.ntis.gov/ordering.htm 


\section{Ride-Through Capability Predictions for Wind Power Plants in the ERCOT Network}

\author{
E. Muljadi ${ }^{1}$ \\ Senior Member IEEE \\ C.P. Butterfield ${ }^{1}$ \\ Member IEEE
}

\author{
J. Conto ${ }^{2}$ \\ Member IEEE
}

\author{
K. Donohoo ${ }^{2}$ \\ Senior Member IEEE
}

\begin{abstract}
Utility system operators and engineers now want a better understanding of the impacts of large wind farms on grid stability before the farms are interconnected to the grid. Utilities need wind farm electrical models and methods of analysis that will help them analyze potential problems of grid stability. Without the necessary tools and knowledge of the behavior of large wind power plants, utilities are reluctant to integrate more wind power into the grid.

The dynamic models used in this paper were developed by Power Technologies Inc. (PTI), under subcontract from ERCOT. A three-phase fault on important buses will be tested, and the potential impact on wind farms will be investigated. Two methods, dynamic analysis and steady state analysis $\left(Z_{b u s}\right.$ prediction), will be used to predict the low voltage ride through capability of the wind farms. Comparison between the two methods will be presented.
\end{abstract}

Index Terms-wind turbine, wind farm, wind energy, aggregation, power system, variable-speed generation, renewable energy, low voltage ride through

\section{INTRODUCTION}

Modern wind turbines are ready for large-scale deployment and play an important role in the utility grid. Despite early stagnation, wind power has grown very fast and has become competitive with other types of generation. The knowledge base accumulated during many years of development is an asset as the technology moves forward. With low penetration of wind power, the utility was not affected by the presence of the wind farm. The loss of generation from a small wind farm was not considered a threat to the security of the overall power system. However, the size of wind farms is increasing, and so is the presence of wind energy in the power grid. More wind farms are being erected in more states-in part because the lead time to build a wind farm is relatively short compared to conventional power plants.

In the early 1980s, large wind farms were built with the support of tax incentives. In the United States, early wind farms were concentrated in California. The size of each wind farm was usually small ( 3 to $70 \mathrm{MW}$ ). As the size of wind turbines has increased and the installation of wind turbines has become more widespread, more utilities will be exposed to wind energy that may affect their power grid. Modern wind farms are large in size (up to $300 \mathrm{MW}$ ) and are often located within a short distance of each other. These wind farms feed the same utility line.

The good news is that the power systems technology has progressed dramatically in the past 20 years. With the advent of power electronics applications, which are designed to firm

\footnotetext{
${ }^{1}$ National Renewable Energy Laboratory, Golden, CO 80401

${ }^{2}$ Electric Reliability Council of Texas, Taylor, TX 76574
}

up the power-systems network, the reliability and security of the power systems have improved.

Although stability studies have been conducted since the early development of wind energy [1], the important question to be answered is still the same: Will a wind farm survive a fault on the grid? How far should the fault be from the wind farm to minimize the number of turbines disconnected from the grid? How do we assess the potential drop-off of a wind farm from the power grid? Is there any easy answer to these questions?

We describe the scope of our investigation in section II. In section III, we discuss the impact of fault location on the bus voltages of a wind farm. In section IV, we describe the methods used to predict the immunity of a wind farm in the presence of a fault. Finally, we summarize our conclusion in Section V.

\section{SCOPE OF INVESTIGATION}

\section{A. Modeling Scope}

The modules used in this investigation are developed by Power Technologies, Inc. (PTI), under subcontract from the Electric Reliability Council of Texas (ERCOT). Detailed information can be found in [2]. A typical module consists of the following input:

- Aerodynamic

- Pitch mechanism

- Wind input

- Shaft dynamic

- Relay protections

- Generator and power electronics

- Control algorithm.

The control algorithm is unique for each wind turbine. In the simulation, all wind turbines installed in the wind plants in the ERCOT area are represented, up to the time when the wind farms were built. The newer wind farms, which were built after the models were developed, are not included in the study.

To represent a more realistic model of the wind farms, the diversity in the wind farms and aggregate impact are included in the models [3-4]. Typical aspects of diversity in a wind farm include the following:

- Spatial distribution

- Line impedance

- Different types of wind turbines

- Different settings and control set-points

- Different settings of relay protections

- Different control strategies

- Different types of reactive power compensation.

This list could be extended. However, if most of the listed 
items are taken into account, the modeled wind farm should be acceptably realistic.

Table I. List of Wind Farms and Types of Turbines

\begin{tabular}{|l|l|l|l|}
\hline Wind Farm Name & $\begin{array}{l}\text { Wind Farm } \\
\text { Rating } \\
\text { (MW) }\end{array}$ & Turbine & $\begin{array}{l}\text { Output } \\
\text { Power } \\
\text { (MW/ } \\
\text { Turbine) }\end{array}$ \\
\hline Desert Sky 2 & 113 & GE1.5 & 1.5 \\
Desert Sky 1 & 113 & GE1.5 & 1.5 \\
King Mountain N.E. & 79.3 & BONUS1300 & 1.3 \\
King Mountain S.E. & 40.3 & BONUS1300 & 1.3 \\
King Mountain S.W. & 79.3 & BONUS1300 & 1.3 \\
King Mountain N.W. & 79.3 & BONUS1300 & 1.3 \\
Woodward 1 & 77.9 & V47 & 0.6 \\
Woodward 2 & 81.8 & V47 & 0.6 \\
Orion/Ind. Mesa & 82.6 & V47 & 0.6 \\
South West Mesa & 81 & NM72 & 1.6 \\
TWPP & 105 & GE1.5 & 1.5 \\
Trent Mesa & 150 & GE1.5 & 1.5 \\
Big Spring & 25.8 & V47 & 0.6 \\
\hline
\end{tabular}

Table I lists the various wind farms, along with the turbines installed within the farms. The Texas map in Fig. 1 indicates ERCOT's jurisdiction, with the square box highlighting the area of greatest concentration of wind farms.

Note that power quality issues are not included in the scope of this paper. Interested readers should refer to [5] for more information on this topic.

\section{B. Regional Scope of Investigation}

The wind farms in the ERCOT region are concentrated in the vicinity of McCamey. Unfortunately, this area has limited outbound transmission. In our investigation, we focus on this McCamey area. The region has different voltage levels. The transmission level has a $345-\mathrm{kV}$ line, and the sub-transmission level has $69-\mathrm{kV}$ and $34.5-\mathrm{kV}$ lines. The distribution level has $10-\mathrm{kV}, 690-\mathrm{V}$, and $600-\mathrm{V}$ lines, which represent the powersystems network in this study.

The system considered is "summer peak 2007," with about 6000 buses, 500 generators actively connected to the grid, and 1000 transformers serving the transmissions system.

\section{IMPACT OF FAULT ON DIFFERENT BUSES}

Fig. 2 depicts the per-phase equivalent circuits of the simplified power system for three different cases. In each equivalent circuit, it shows the components of the system, including three buses. The wind farm generation is shown as connected to bus 1 . The power generated by a wind turbine is connected to a transformer at each pad mount. The power from each turbine is then collected at the substation located near the wind farm. All buses are interconnected by the electrical lines, which transmit the real and reactive power in any direction.

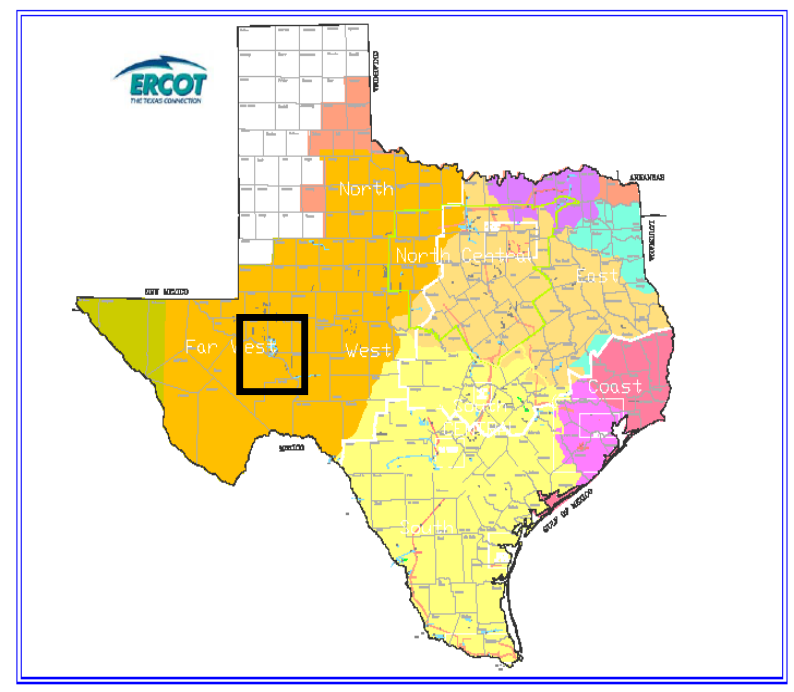

Fig. 1. ERCOT's power-system network, with the square box highlighting the area of wind farms in the network.

\section{A. Operation Under Normal Condition}

Fig. 2a describes a normal condition. In this illustration, we assume that the wind farm is relatively small with respect to the larger power network to which it is connected. The simple one-line diagram shows three buses and an infinite bus. Bus 1 is connected to a wind farm, bus 2 is connected to a load, and bus 3 is connected to both bus 1 and bus 2 . Under normal conditions, the currents flowing in the circuit do not create a large voltage drop across impedances $\left(I_{s} Z_{s}\right.$ and $I_{W F}$ $Z_{1}$ ); thus, the voltages at bus 1 and bus 2 are practically closed to per unit under normal conditions.

The equation describing the voltage at the wind farm can be written as follows:

$$
\mathrm{V}_{1}=\mathrm{E}_{\mathrm{s}}-\mathrm{I}_{\mathrm{s}} \mathrm{Z}_{\mathrm{s}}+\mathrm{I}_{\mathrm{WF}} \mathrm{Z}_{1}
$$

where:

$\mathrm{Z}_{\mathrm{s}}=$ transmission line and transformer impedance between bus 0 (infinite bus) and bus 3 (very small);

$\mathrm{Z}_{1}=$ distribution line and transformer impedance between bus 3 and bus 1 ;

$\mathrm{Z}_{2}=$ distribution line and transformer impedance between bus 3 and load bus 2 (much larger than $Z_{s}$ and $Z_{1}$, as indicated by the thickness of the line representing the impedance $Z_{2}$ ).

\section{B. Operation Under Fault Condition}

Many types of faults may occur in a wind farm power system. In this paper, only the three-phase symmetrical fault will be investigated because this fault generates the highest fault current. This type of analysis is necessary to properly size switchgear to protect the power system. From the point of view of location, two types of faults exist: near faults and far faults. In near faults, the voltage at the wind farm is practically zero. In far faults, depending on the impedance of the line, the voltage at the wind farm does not go completely to zero. Fig. 2 shows a per-phase equivalent circuit describing far-fault and near-fault conditions. 


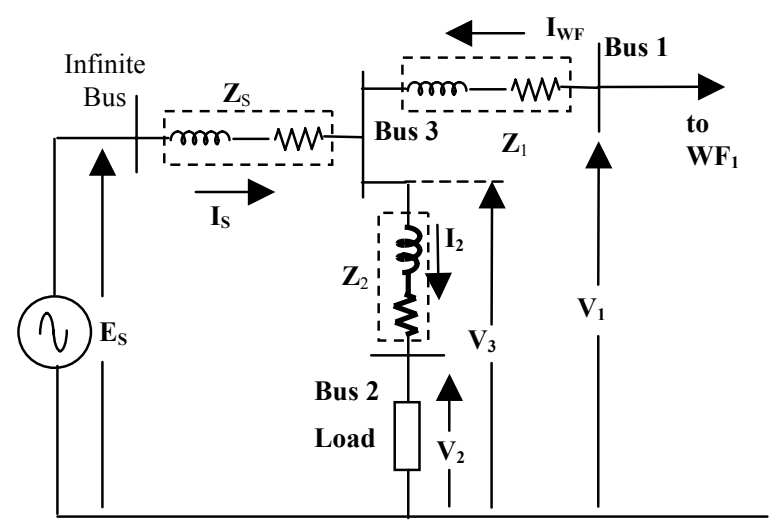

(a)
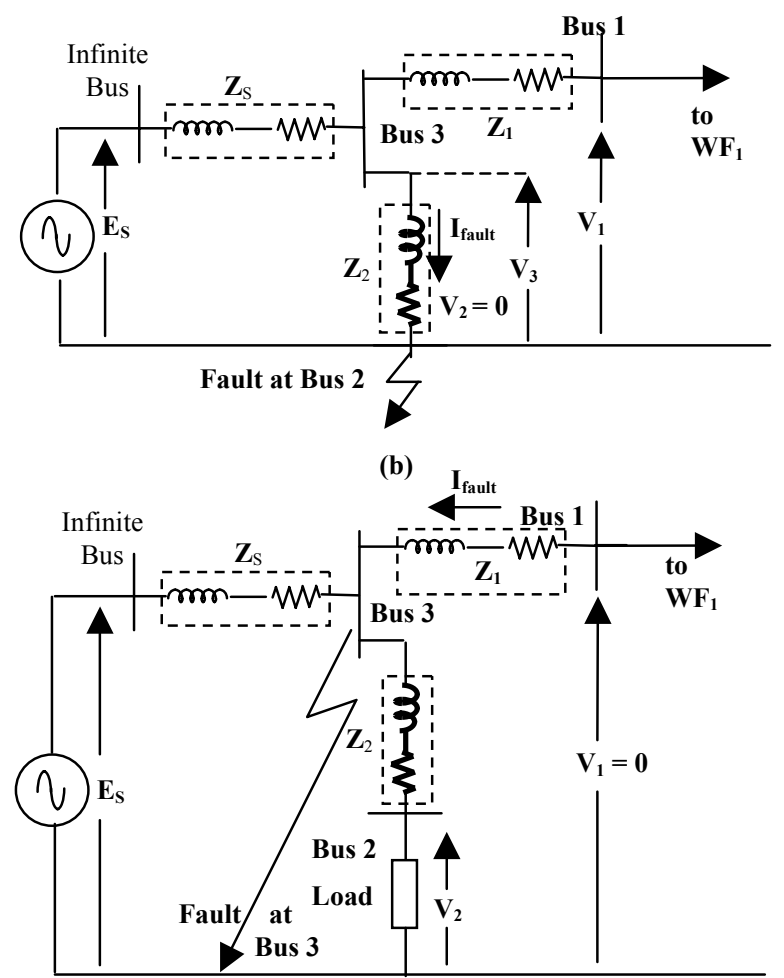

(c)

Fig. 2. Per-turbine, per-phase equivalent circuit of a wind farm connected to a larger power-system network: (a) normal condition, (b) far-fault condition, and (c) near-fault condition.

\section{1) Far-Fault Condition:}

Under fault condition, the fault current is very large compared to normal current $I_{s}$ or $I_{W F}$. For the purpose of illustration, we can neglect this normal current. The voltage at bus 1 can be computed as:

$$
\mathrm{V}_{3}=\mathrm{E}_{\mathrm{s}} \mathrm{Z}_{2} /\left(\mathrm{Z}_{\mathrm{s}}+\mathrm{Z}_{2}\right)
$$

Voltage drop across $Z_{1}$ because of normal current is neglected:

$$
\mathrm{V}_{1}=\mathrm{V}_{3}
$$

Thus, if the relative size of the impedance $Z_{2}$ is large compared to $Z_{\mathrm{s}}\left(Z_{2}>>Z_{\mathrm{s}}\right)$, the voltage dip during the fault on bus 3 and bus 2 may be shallow. This situation is categorized as a far-fault condition. The voltage during the fault presented to bus 3 will be smaller and shifted by a phase angle determined by the nature of the impedances $Z_{s}$ and $Z_{2}$.

\section{2) Near-Fault Condition:}

For a situation in which the impedance $Z_{2}$ is small compared to the impedance $Z_{\mathrm{s}}$ - or if, for example, the fault occurs at bus 3 - then the voltage at bus 3 and bus 1 will drop to zero during the fault.

$$
\mathrm{V}_{3}=\mathrm{E}_{\mathrm{s}} 0 /\left(\mathrm{Z}_{\mathrm{s}}+0\right)
$$

and

$$
\mathrm{V}_{1}=\mathrm{V}_{3}=0
$$

Therefore, the voltage conditions at bus 1 and bus 3 have shown that the resulting bus voltages drop to zero.

\section{3) Other Possible Conditions:}

The condition presented in 2) above must be examined further for other variations. For example, the bus voltage on bus 1 may not drop too low because of the voltage across the impedance $Z_{1}$ if: a) there are other generators connected to bus $1, b)$ the wind generation from bus 2 is large, c) the size of $Z_{1}$ is significantly large, d) the fault is a fault through nonzero impedance, or e) combinations of a to $\mathrm{d}$.

$$
\mathrm{V}_{1}=\mathrm{I}_{\text {FAULT_1 }_{-}} \mathrm{Z}_{1} \text {. }
$$

In this case, the bus voltage on bus 1 may not drop to zero because of the voltage across the impedance $Z_{1}$.

\section{LOW-Voltage RIDE-THROUGH CAPABILITY}

In the early stages of the development of wind energy, only a few wind turbines were connected to the grid. In this situation, when a fault somewhere in the lines caused the voltage at the wind turbine to drop, the wind turbine was simply disconnected from the grid and was reconnected when the fault was cleared and the voltage returned to normal. Thus, because the penetration of wind power in the early days was low, the sudden disconnection of a wind turbine or even a wind farm from the power grid did not cause a significant impact on the stability of the power system; the loss of generation from the wind farm was simply supplied by other generators. With the increasing penetration of wind energy, the contribution of power generated by a wind farm can be significant. If the entire wind farm is suddenly disconnected at full generation, the impact on the power system can be dramatic. Therefore, the new generation of wind turbines must be able to "ride through" during disturbances and faults to avoid total disconnection from the grid.

\section{A. Systems and Dynamic Analyses Description}

We explained earlier that diversity exists in real wind farm power systems. The diversity in a large wind farm is handled by using different collector points, which represent groups of 
wind turbines with similar characteristics. A very large wind

farm will have several collector points.

The nature of the faults can be diverse. However, in this paper, we only consider the three-phase to ground fault.

We have removed sensitive information, such as the type of turbines and specific locations of turbines being studied. The data presented in this paper will be masked to protect proprietary information.

Several types of wind turbines can be found in the ERCOT area, including the following:

1) Variable-speed doubly fed induction generator with pitch control and power electronics (partial conversion power converter)

2) Variable-speed squirrel cage induction generator with pitch control and power electronics (full-conversion power converter)

3) Variable slip with pitch control

4) Fixed speed with stall control

5) Fixed speed with pitch control.

In this section, we perform dynamic analysis using models of wind turbines developed by ERCOT with a subcontract to PTI. The software used is Power Systems Simulations for Engineers (PSS/E). Each wind farm is equipped with different turbine configurations. To include diversity in the analysis, a large wind farm may be split into several collector buses to represent a unique group of turbines from different perspectives (e.g., types of turbine, controller setting, length of line feeders, spatial diversity of wind speed within the wind farm). The method faults one specific bus at a time, then observes the response on the entire wind farm. For a faulted bus, the fault is designed to last 4 cycles $(66.7 \mathrm{~ms})$ and is then cleared.

The dynamic simulation was prepared based on ERCOT's entire grid. The dynamic models are generated by the IPLAN program provided by PTI as part of the package program. The IPLAN program generates the dynamic model and adds the new generators (wind farms) into the original input data (raw data). The wind farms are scaled to the correct size based on the grouping described above. The correct reactive power compensation is calculated in the IPLAN program. Within the IPLAN program, the proper initialization is also included as part of the process.

The dynamic program includes the relay protections based on voltage and frequency relay. Upper and lower limits and time delays can be set, and default values can also be used. In this study, the relay protections were set to the default values, and no attempt was made to change the default settings. Obviously, with different settings, the outcome of the simulation would also be affected.

Batch commands are prepared as an IDEV file to enable multiple and sequential simulation runs, and the output can be redirected for future use and analysis.

\section{B. Fault on Selected Buses Based on Distance}

Above, we explained near and far faults. Although the terms "near" and "far" are commonly used to express the geographical distance from one point to another, the more appropriate explanation is the electrical distance from one node with respect to the other.

Several types of faults can be studied according to many different situations. However, in this paper, our investigation is limited to a symmetrical three-phase to ground fault situation, in which the fault current is the most severe type of fault.

A list of buses to be tested follows. The distinction of which nodes or buses should be faulted is based on the voltage bus and the approximate distance from the center of the wind farms area.

\section{9-kV Line:}

Near Fault:

1) Texas New Mexico 6606

2) Sun Valley 6641

3) Harrell Branch 3554

4) Rankin 6589

Far Fault:

1) Ward Sw. 7312

2) Fort Stockton 6628

3) Pucket Field 38460

4) Illinois No. 46565

5) Barnhart 6530

6) Reagan Shell 1216

\section{8-kV Line:}

Near Fault:

1) Crane 6615

2) Ft. Stockton 6630

3) Ft. Lancaster 6579

4) Big Lake 6535

\section{Far Fault:}

1) Barilla Jct. 6655

2) Sonora 6515

3) Spraberry 1330

\section{5-kV Line:}

Far Fault: Odessa 1027

Fig. 3 is a map of proposed faults, with fault locations identified by different markers, shapes, and colors indicating near faults or far faults. The results of the simulations for each fault are tabulated, and the loss of generated power because of the faults was recorded to rank the severity of the fault impacts.

Table II shows that for the majority of buses listed, a threephase to ground fault on the bus does not cause a significant loss of wind power generation. None of the $69-\mathrm{kV}$ buses on the list, far or near, cause any trips on the wind farms. Most of the wind farms were disconnected when there was a bus fault of $138 \mathrm{kV}$ on bus 6615 . This bus is the McCamey bus, considered to be a weak link between the area and the rest of the power network within ERCOT. Faults on other buses, such as a fault on bus 6630 or on bus 6579 , caused only minor disruption, with a total production loss of $91 \mathrm{MW}$ and 113 MW, respectively. None of the far faults being observed- 


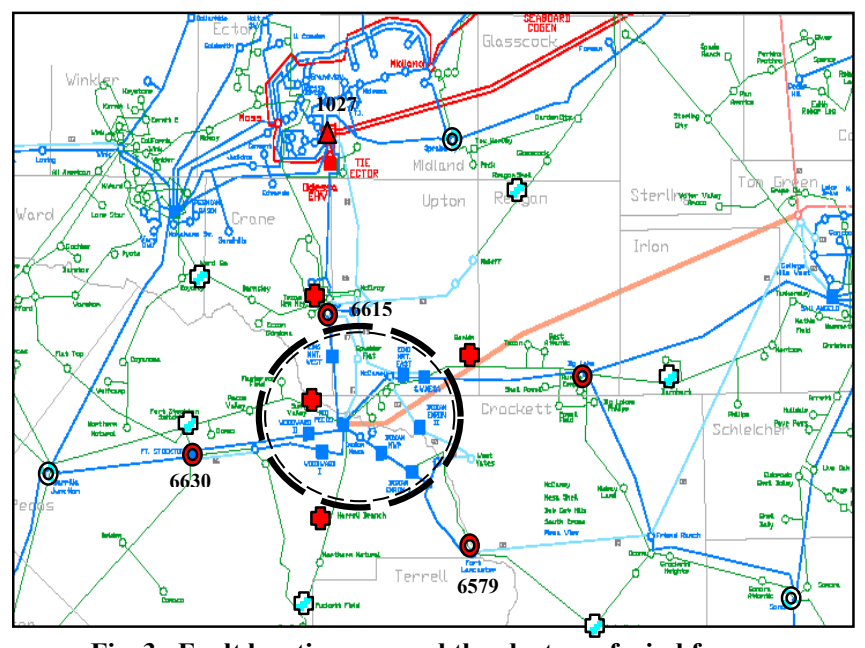

Fig. 3. Fault locations around the clusters of wind farms.

Table II. List of Affected Productions of Wind Farms

\begin{tabular}{|l|c|c|c|c|c|c|c|}
\hline Voltage & \multicolumn{2}{|c|}{$\mathbf{6 9} \mathbf{k V}$} & \multicolumn{3}{|c|}{$\mathbf{1 3 8}-\mathbf{k V}$ Near } & $\mathbf{1 3 8} \mathbf{k V}$ & $\mathbf{3 4 5} \mathbf{k V}$ \\
\hline WFarm & Near & Far & $\mathbf{6 6 1 5}$ & $\mathbf{6 6 3 0}$ & $\mathbf{6 5 7 9}$ & $\mathbf{F a r}$ & $\mathbf{1 0 2 7}$ \\
\hline WF1 & $\mathrm{O}$ & $\mathrm{O}$ & $\mathbf{X}$ & $\mathrm{O}$ & $\mathbf{X}$ & $\mathrm{O}$ & $\mathrm{O}$ \\
WF2 & $\mathrm{O}$ & $\mathrm{O}$ & $\mathbf{X}$ & $\mathrm{O}$ & $\mathrm{O}$ & $\mathrm{O}$ & $\mathrm{O}$ \\
WF3 & $\mathrm{O}$ & $\mathrm{O}$ & $\mathbf{X}$ & $\mathrm{O}$ & $\mathrm{O}$ & $\mathrm{O}$ & $\mathrm{O}$ \\
WF4 & $\mathrm{O}$ & $\mathrm{O}$ & $\mathbf{X}$ & $\mathrm{O}$ & $\mathrm{O}$ & $\mathrm{O}$ & $\mathrm{O}$ \\
WF5 & $\mathrm{O}$ & $\mathrm{O}$ & $\mathbf{X}$ & $\mathrm{O}$ & $\mathrm{O}$ & $\mathrm{O}$ & $\mathrm{O}$ \\
WF6 & $\mathrm{O}$ & $\mathrm{O}$ & $\mathbf{X}$ & $\mathrm{O}$ & $\mathrm{O}$ & $\mathrm{O}$ & $\mathrm{O}$ \\
WF7 & $\mathrm{O}$ & $\mathrm{O}$ & $\mathrm{O}$ & $\mathrm{O}$ & $\mathrm{O}$ & $\mathrm{O}$ & $\mathrm{O}$ \\
WF8 & $\mathrm{O}$ & $\mathrm{O}$ & $\mathrm{O}$ & $\mathrm{O}$ & $\mathrm{O}$ & $\mathrm{O}$ & $\mathrm{O}$ \\
WF9 & $\mathrm{O}$ & $\mathrm{O}$ & $\mathrm{O}$ & $\mathrm{O}$ & $\mathrm{O}$ & $\mathrm{O}$ & $\mathrm{O}$ \\
WF10 & $\mathrm{O}$ & $\mathrm{O}$ & $\mathbf{X}$ & $\mathbf{X}$ & $\mathrm{O}$ & $\mathrm{O}$ & $\mathbf{X}$ \\
WF11 & $\mathrm{O}$ & $\mathrm{O}$ & $\mathrm{O}$ & $\mathrm{O}$ & $\mathrm{O}$ & $\mathrm{O}$ & $\mathrm{O}$ \\
WF12 & $\mathrm{O}$ & $\mathrm{O}$ & $\mathrm{O}$ & $\mathrm{O}$ & $\mathrm{O}$ & $\mathrm{O}$ & $\mathrm{O}$ \\
WF13 & $\mathrm{O}$ & $\mathrm{O}$ & $\mathrm{O}$ & $\mathrm{O}$ & $\mathrm{O}$ & $\mathrm{O}$ & $\mathrm{O}$ \\
WF14 & $\mathrm{O}$ & $\mathrm{O}$ & $\mathrm{O}$ & $\mathrm{O}$ & $\mathrm{O}$ & $\mathrm{O}$ & $\mathrm{O}$ \\
WF15 & $\mathrm{O}$ & $\mathrm{O}$ & $\mathrm{O}$ & $\mathrm{O}$ & $\mathrm{O}$ & $\mathrm{O}$ & $\mathrm{O}$ \\
\cline { 2 - 8 } Total & & & & & & & \\
Loss & $\mathbf{0}$ & $\mathbf{0}$ & $\mathbf{5 9 5 . 2}$ & $\mathbf{9 1}$ & $\mathbf{1 1 3}$ & $\mathbf{0}$ & $\mathbf{9 1}$ \\
\hline
\end{tabular}

neither a fault on the $69-\mathrm{kV}$ buses, nor a fault on the $138-\mathrm{kV}$ buses - caused a disconnection of any wind farms. On the $345-\mathrm{kV}$ transmission line in the area, a fault at bus 1027 caused a small disruption, with a total loss of $91 \mathrm{MW}$.

\section{C. $Z_{B U S}$ Prediction (Steady State Analysis)}

From results presented in section $B$, it is obvious that we can choose several "fault-prone" buses and perform an analysis by running the dynamic program to check whether any wind farms will be removed from the grid during a fault. However, how do we decide which buses to choose? The concept of near fault or far fault is all relative for a complex power network.

Now, let us consider a new approach. From the power system analysis, we have used the load flow analysis, based on the Node Analysis, which finds the bus voltages using different methods of iteration (e.g., Newton-Raphson, etc.). The power flow analysis basically solves the following iteration:

$$
[\mathbf{I}]=[\mathbf{Y}][\mathbf{V}]
$$

where:

$[\mathbf{Y}]$ is the Ybus with $\mathrm{n} \times \mathrm{n}$ representing $\mathrm{n}$ buses

[I] is the column matrix $\mathrm{n} \times 1$ matrix representing currents

[V] is the column matrix nx1 matrix representing bus voltages.

The inverse to the $\mathrm{Y}_{\text {bus }}$ is called $\mathrm{Z}_{\text {bus }}$ :

$$
[\mathbf{Z}]=[\mathbf{Y}]^{-1}
$$

Many methods can be used to get $Z_{\text {bus }}$, but in this paper, the arrival to $Z_{\text {bus }}$ is not emphasized. One use of $Z_{\text {bus }}$ is to get information on the impact of changes in current injection in one bus on other buses. While $\mathrm{Y}_{\text {bus }}$ represents the admittance from a node or between two nodes, in the $Z_{\text {bus }}$, the element of $Z_{\text {bus }}$ does not represent the actual line impedance between two nodes. $Z_{\text {bus }}$ provides information on the impact that changes in current injection at one bus have on other buses. This simple concept is used in this paper to analyze the sensitivity of the current injection changes in any particular bus on the wind farm buses. We are particularly interested in major perturbations, such as a short circuit on one bus and its impact on wind power generation.

We started by finding the short-circuit current on certain buses of interest. It is important to find out the consequence of the short-circuit current on the bus voltage at the wind farm buses.

A simple example of a $Z_{\text {bus }}$ is shown in equation IV-3 below:

$$
Z_{b u s}=\left(\begin{array}{ccccc}
Z_{11} & \cdot & Z_{1 m} & \cdot & Z_{1 n} \\
\cdot & \cdot & \cdot & \cdot & \cdot \\
Z_{m 1} & \cdot & Z_{m m} & \cdot & Z_{m n} \\
\cdot & \cdot & \cdot & \cdot & \cdot \\
Z_{n 1} \cdot & \cdot & Z_{n m} & \cdot & Z_{n n}
\end{array}\right)
$$

Let us assume that bus $\mathrm{m}$ is the node where a fault has occurred, and bus $\mathrm{n}$ is the node where a wind farm is connected to the grid. The short-circuit current at bus $\mathrm{m}$ can be computed as:

$$
I_{S C}=\frac{V_{m o}}{Z_{m m}}
$$

where:

$\mathrm{V}_{\text {mo }}=$ bus voltage pre-fault condition

$\mathrm{I}_{\mathrm{SC}}=$ short-circuit current for a fault at bus $\mathrm{m}$

$\mathrm{Z}_{\mathrm{mm}}=$ driving-point impedance of bus $\mathrm{m}$.

The pre-fault bus voltage at bus $\mathrm{m}\left(\mathrm{V}_{\mathrm{mo}}\right)$ is generally the 
voltage under normal condition ( $\sim 1.0$ per unit), and the driving point impedance $\left(Z_{\mathrm{mm}}\right)$ represents the effective Thevenin impedance seen from bus $\mathrm{m}$. The short-circuit current $\left(\mathrm{I}_{\mathrm{SC}}\right)$ assumes that this is a three-phase to ground-phase fault. The impact of the fault on another bus can be expressed as:

$$
\Delta V_{n}=-I_{S C} Z_{n m}
$$

where:

$\Delta \mathrm{V}_{\mathrm{n}}=$ change in bus voltage during the fault condition

$\mathrm{Z}_{\mathrm{nm}}=$ transfer impedance.

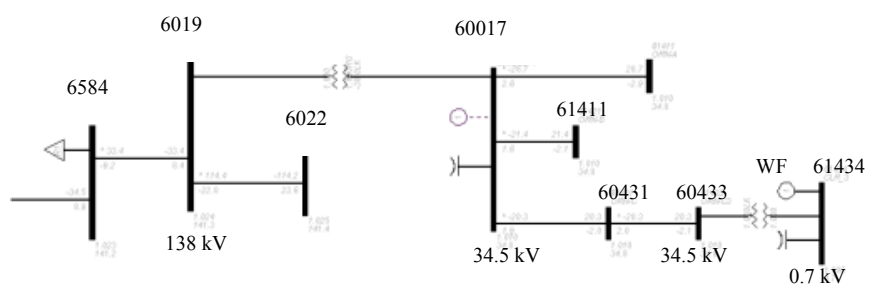

Fig. 4. Single-line diagram of buses surrounding a wind farm.

With the help of the transfer bus impedance, we can gauge the impact of the fault occurring at bus $m$ on another bus. To guide us in choosing which buses would be tested, we traced the single-line diagram from the point of wind farm generation, upstream to higher bus voltages. We created a three-phase to ground fault on those buses, checked the voltage drops on the wind farm bus of interest, and tabulated the voltage drops on the buses surrounding the wind farm. An example of a single-line diagram of one particular wind farm is given in Fig. 4. The bus number and voltage rating of the buses are listed.

For example, we might want to create a fault on the following buses, one bus at a time: 60433, 60431, 61411, 60017,6019 , and 6584. Then, every time we have a fault on a bus, we can check for the corresponding voltage drop on the wind farm bus (bus 61434). The voltage drop on the wind farm bus because of the faults on each bus surrounding the wind farm is calculated using the $Z_{\text {bus }}$ method. Those voltage drops on the wind farms that are below a certain threshold specified are considered to cause disconnection of the wind farm from the grid. This is a crude estimate because, in practice, most of the faults are cleared after four cycles. Thus, in this analysis, we assumed that the fault creates a voltage drop that may not be restored. The existence of the relay protection and the corresponding set points are neglected. In this method, the criterion to drop a wind farm from the grid is when the voltage at the wind farm drops below $80 \%$ of normal ( $\mathrm{V}<0.8$ p.u.).

As an example, Table III represents a list of wind farms dropped off line. The top row of the table represents the name of the buses where the fault occurred. The first column of the table represents the name of the wind farms (WF1 to WF15). The bottom row of the table indicates the total generated power loss predicted by the $Z_{\text {bus }}$ method based on the assumption that a voltage drop of $20 \%$ or higher at a wind farm bus during a fault at a selected bus cannot survive a post- fault condition.

Table III. Loss of Generation $Z_{\text {bus }}$ Prediction Method

\begin{tabular}{|l|c|c|c|c|c|c|} 
Voltage & $138 \mathrm{kV}$ & $138 \mathrm{kV}$ & $138 \mathrm{kV}$ & $138 \mathrm{kV}$ & $34.5 \mathrm{kV}$ & $34.5 \mathrm{kV}$ \\
\hline
\end{tabular}

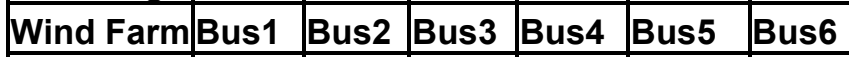

WF1

WF2

WF3

WF4

WF5

WF6

WF7

WF8

WF9

WF10

WF11

WF12

WF13

WF14

WF15

\begin{tabular}{|c|c|c|c|c|c|}
\hline$X$ & $X$ & $X$ & $X$ & 0 & 0 \\
\hline$X$ & $X$ & $X$ & $X$ & 0 & 0 \\
\hline$x$ & $X$ & $X$ & $X$ & 0 & 0 \\
\hline$X$ & $X$ & $X$ & $X$ & 0 & 0 \\
\hline$X$ & $X$ & $X$ & 0 & 0 & 0 \\
\hline$X$ & $X$ & $X$ & 0 & $\mathrm{O}$ & 0 \\
\hline$X$ & $X$ & $X$ & $X$ & 0 & 0 \\
\hline$X$ & $X$ & $X$ & $X$ & 0 & 0 \\
\hline$x$ & $X$ & $X$ & $X$ & 0 & 0 \\
\hline$X$ & $X$ & $X$ & $X$ & $X$ & $X$ \\
\hline 0 & 0 & $\mathrm{O}$ & 0 & 0 & 0 \\
\hline 0 & 0 & 0 & 0 & 0 & 0 \\
\hline 0 & 0 & 0 & 0 & 0 & 0 \\
\hline O & O & O & 0 & $\mathrm{O}$ & $\mathrm{O}$ \\
\hline 0 & 0 & 0 & 0 & 0 & 0 \\
\hline 826.5 & 826.5 & 826.5 & 282.8 & 77.9 & 77.9 \\
\hline
\end{tabular}

\begin{tabular}{l|c|c|}
\hline Total Loss & 826.5 & 826.5 \\
\hline$\Delta \mathrm{V}>20 \%$ & (Voltage Drop)
\end{tabular}

In reality, the relay protections and the circuit-breaker settings (e.g., upper and lower limit cut-off, time delay) would determine whether a wind farm should be disconnected from the grid or should remain connected. The X mark in each cell indicates that the corresponding wind farm is affected (some or all of the turbines are disconnected), whereas the $\mathrm{O}$ mark in each cell indicates that the corresponding wind farm is not affected by the fault on this particular bus. The marking convention is a way to mask the identity of the wind farm. And the bus number has been renumbered for the same reason.

The table shows that the higher the bus voltage rating, the greater the number of turbines dropped from the grid (as shown, a significant loss in wind power generation), whereas the closer the buses are to the wind farm (as the voltage level changes into the distribution level), the fewer the number of wind farms dropped from the line.

\section{Comparison between Dynamic Model and $Z_{B U S}$ Prediction}

Note that the $Z_{\text {bus }}$ prediction is a steady-state analysis that does not include all the relay protections and other settings. The time delay, duration, and level of the faults are not considered in this analysis. To check the validity of the $Z_{\text {bus }}$ prediction, we have the entire ERCOT system simulated using a dynamic model (PSS/E software). The results are compared to the $Z_{\text {bus }}$ prediction method. The dynamic models of the wind farms are equipped with relay protection for under/over voltage or frequency, including the timer settings of the circuit breakers. As mentioned before, the short circuit is placed on the selected bus for a period of four cycles, and the fault is then cleared.

For this analysis, the maximum output power of the disconnected wind farms caused by the faults are recorded and 
tabulated in Table IV.

Table IV. Loss of Generation, Based on Dynamic Model

\begin{tabular}{|l|c|c|c|c|c|c|}
\hline Voltage & 138kv & $\mathbf{1 3 8 k V}$ & $\mathbf{1 3 8 k V}$ & $\mathbf{1 3 8 k V}$ & $\mathbf{3 4 . 5 k V}$ & $\mathbf{3 4 . 5 k V}$ \\
\hline Wind Farm & Bus1 & Bus2 & Bus3 & Bus4 & Bus5 & Bus6 \\
\hline WF1 & $\mathrm{X}$ & $\mathrm{X}$ & $\mathrm{X}$ & $\mathrm{X}$ & $\mathrm{O}$ & $\mathrm{O}$ \\
WF2 & $\mathrm{X}$ & $\mathrm{X}$ & $\mathrm{X}$ & $\mathrm{X}$ & $\mathrm{O}$ & $\mathrm{O}$ \\
WF3 & $\mathrm{X}$ & $\mathrm{O}$ & $\mathrm{X}$ & $\mathrm{O}$ & $\mathrm{O}$ & $\mathrm{O}$ \\
WF4 & $\mathrm{X}$ & $\mathrm{O}$ & $\mathrm{X}$ & $\mathrm{O}$ & $\mathrm{O}$ & $\mathrm{O}$ \\
WF5 & $\mathrm{X}$ & $\mathrm{O}$ & $\mathrm{X}$ & $\mathrm{O}$ & $\mathrm{O}$ & $\mathrm{O}$ \\
WF6 & $\mathrm{X}$ & $\mathrm{O}$ & $\mathrm{X}$ & $\mathrm{O}$ & $\mathrm{O}$ & $\mathrm{O}$ \\
WF7 & $\mathrm{O}$ & $\mathrm{O}$ & $\mathrm{O}$ & $\mathrm{O}$ & $\mathrm{O}$ & $\mathrm{O}$ \\
WF8 & $\mathrm{O}$ & $\mathrm{O}$ & $\mathrm{O}$ & $\mathrm{O}$ & $\mathrm{O}$ & $\mathrm{O}$ \\
WF9 & $\mathrm{O}$ & $\mathrm{O}$ & $\mathrm{O}$ & $\mathrm{O}$ & $\mathrm{O}$ & $\mathrm{O}$ \\
WF10 & $\mathrm{X}$ & $\mathrm{X}$ & $\mathrm{X}$ & $\mathrm{X}$ & $\mathrm{O}$ & $\mathrm{O}$ \\
WF11 & $\mathrm{O}$ & $\mathrm{O}$ & $\mathrm{O}$ & $\mathrm{O}$ & $\mathrm{O}$ & $\mathrm{O}$ \\
WF12 & $\mathrm{O}$ & $\mathrm{O}$ & $\mathrm{O}$ & $\mathrm{O}$ & $\mathrm{O}$ & $\mathrm{O}$ \\
WF13 & $\mathrm{O}$ & $\mathrm{O}$ & $\mathrm{O}$ & $\mathrm{O}$ & $\mathrm{O}$ & $\mathrm{O}$ \\
WF14 & $\mathrm{O}$ & $\mathrm{O}$ & $\mathrm{O}$ & $\mathrm{O}$ & $\mathrm{O}$ & $\mathrm{O}$ \\
WF15 & $\mathrm{O}$ & $\mathrm{O}$ & $\mathrm{O}$ & $\mathrm{O}$ & $\mathrm{O}$ & $\mathrm{O}$ \\
Total Loss & $\mathbf{5 8 5 . 2}$ & $\mathbf{3 0 7}$ & $\mathbf{5 8 5 . 2}$ & $\mathbf{1 7 2}$ & $\mathbf{0}$ & $\mathbf{0}$ \\
\hline
\end{tabular}

Some of the cells in Table IV are shaded to identify the cells previously disconnected based on a $20 \%$ voltage drop predicted by the $Z_{\text {bus }}$ methods. Shown here is the discrepancy between the two methods $\left(Z_{\text {bus }}\right.$ prediction versus dynamic model). For example, in the dynamic model simulation, wind farms WF7 through WF9 were never affected by any of the faults at any buses under observation, while the Zbus method predicts that the faults on bus 1 through bus 4 will drop some or all of the wind turbines on WF7 through WF9. For a fault on bus 2, wind farms WF3 through WF9 stay connected when dynamic simulation was performed; but based on $Z_{\text {bus }}$ predictions, they are disconnected (the voltage drop at those wind farms exceed 20\%). The difference between the results from the dynamic models and the $Z_{\text {bus }}$ prediction can be significant. The $Z_{\text {bus }}$ prediction gives more pessimistic results compared to the results from the dynamic modeling.

Based on this observation, we want to modify the $Z_{\text {bus }}$ prediction methods by including the indication shown from the dynamic modeling. For example, for the buses indicated in the dynamic modeling, we can be sure that the relay protection and the system dynamic of the power systems have prevented the wind turbines in wind farms WF7 through WF9 from tripping out of the grid. Thus, this information will be used to improve the prediction by excluding, with a certain confidence, that the WF7-WF9 wind farms are immune to the faults on those buses. After several runs, we can make a rule to include the impact of the dynamic model (e.g., relay settings, level and duration of the faults). For example, from Table IV, we can make a rule that WF7-WF9 will never be disconnected from the grid for the type of fault under investigation. Thus, if from the $Z_{\text {bus }}$ calculation, it is shown that one or more of the WF7-WF9 wind farms were disconnected from the grid for the fault prescribed, we should ignore this result and adjust the table accordingly.

Table V. $Z_{\text {bus }}$ Method and Dynamic Model Prediction

\begin{tabular}{|l|l|l|l|l|l|}
\hline Voltage & $\mathbf{1 3 8 k V}$ & $\mathbf{1 3 8 k V}$ & $\mathbf{1 3 8 k V}$ & $\mathbf{1 3 8 k V}$ & $\mathbf{1 3 8 k V}$ \\
\hline Bus Numbers & 1.1 & 1.2 & 1.3 & 1.4 & 1.5 \\
\hline $\mathbf{Z}_{\text {bus }}(\mathbf{2 0 \%} \mathbf{V}$ drop) & 826.5 & 826.5 & 826.5 & 507.6 & 347.9 \\
\hline Adjusted 20\% & 583.5 & 583.5 & 583.5 & 264.6 & 264.9 \\
\hline Dynamic Model & 585.2 & 307 & 585.2 & 893.5 & 585.2 \\
\hline
\end{tabular}

\begin{tabular}{|c|c|c|c|c|c|c|}
\hline $\mathbf{1 3 8 k V}$ & $\mathbf{1 3 8 k V}$ & $\mathbf{1 3 8 k V}$ & $\mathbf{1 3 8 k V}$ & $\mathbf{1 3 8 k V}$ & $\mathbf{3 4 . 5 k V}$ & $\mathbf{3 4 . 5 k V}$ \\
\hline 1.6 & 1.7 & 1.8 & 1.9 & 1.10 & 1.11 & 1.12 \\
\hline 347.9 & 427.2 & 666.8 & 826.5 & 666.8 & 112.5 & 112.5 \\
\hline 264.9 & 344.2 & 583.8 & 583.5 & 583.8 & 113 & 113 \\
\hline 585.2 & 585.2 & 585.2 & 307 & 585.2 & 113 & 0 \\
\hline
\end{tabular}

The results are listed in Table V. The first row indicates the generated power from the wind farms during the fault, as predicted by the $Z_{\text {bus }}$ calculation. The second row is the modified $Z_{\text {bus }}$ calculation based on what we learned from dynamic simulation and shows how some of the wind farms are well protected. The last row is the result from a dynamic calculation. It is interesting to compare the bottom two rows. From the comparison, we can tell that there is agreement between the results from the dynamic model and the results from $Z_{\text {bus }}$ calculation. If there is a difference, the $Z_{\text {bus }}$ prediction is usually too conservative and indicates more generators dropped off the grid.

\section{CONCLUSION}

This paper presents two alternatives of predicting the lowvoltage ride-through capabilities of a wind farm. Two alternatives were used to predict the outcome in the post-fault conditions.

A simple steady-state analysis with a $Z_{\text {bus }}$ matrix of the systems is used. In this method, we use voltage drop on wind farm buses as a criterion to keep the wind farm on line or to drop it off line.

Dynamic simulation of a wind farm is also used. Dynamic simulation is slow and time consuming for a large network. However, it is still possible to check faults on several buses and determine the impact of the faults on the wind farms. In dynamic simulation, the dynamic of the wind turbines, relay protection, and circuit-breaker settings are included. Thus, compared to the $Z_{\text {bus }}$ method, the dynamic simulation will give a better prediction.

From the results presented, in most cases, the $Z_{\text {bus }}$ method shows a more conservative approach than the dynamic simulation approach. Subsequently, we modified the prediction by inserting the knowledge we learned from the dynamic simulations. Therefore, we can come with a better conclusion to "filter" the result from the $Z_{\text {bus }}$ analysis. This "filter" is necessary because the $Z_{\text {bus }}$ approach is rudimentary; it is just a steady-state prediction without the inclusion of relay 
protection and other control systems into the picture. The modified $Z_{\text {bus }}$ method can be used to predict the immunity of a wind farm to faults on buses.

\section{ACKNOWLEDGMENT}

We acknowledge the support of the U.S. Department of Energy. We also thank Yuriy Kazachkov from Power Technologies, Inc., Cathey Carter from ERCOT, and Russel Young from Florida Power and Light Energy, LLC, for help and discussions during the development of this project.

\section{REFERENCES}

[1] E.N. Henrichsen and P.J. Nolan, "Dynamic stability of wind turbine generators," IEEE Trans. Power App. Syst., Vol. PAS-101, pp. 26402648, Aug. 1982.

[2] Y.A. Kazachov, J.W. Feltes, and R. Zavadil, "Modeling wind farms for power system stability studies," in Power Engineering Society General Meeting, 2003, IEEE, Vol. 3, July 2003.

[3] E. Muljadi, C.P. Butterfield, and V. Gevorgian, "The impact of the output power fluctuation of a wind farm on a power grid," in Conference Record:Third International Workshop on Transmission Networks for Offshore Wind Farms, Royal Institute of Technology, Stockholm, Sweden, April 2002.

[4] E. Muljadi and C.P. Butterfield, "Dynamic Model for Wind Farm Power Systems," Global Wind Power Conference, Chicago, Illinois, March/April 2004.

[5] IEC Standard 61 400-21: Measurement and Assessment of Power Quality of Grid Connected Wind Turbines, International Electrotechnical Commission. 


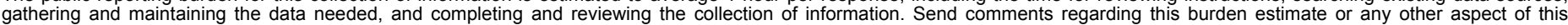

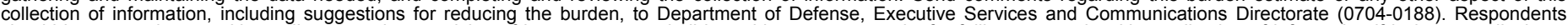

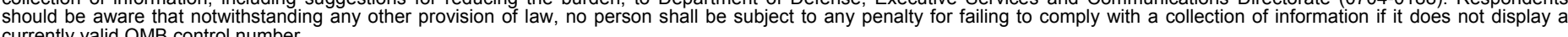

PLEASE DO NOT RETURN YOUR FORM TO THE ABOVE ORGANIZATION.
1. REPORT DATE (DD-MM-YYYY) January 2005
4. TITLE AND SUBTITLE
Ride-Through Capability Predictions for Wind Power Plants in the ERCOT Network: Preprint

3. DATES COVERED (From - To)

5a. CONTRACT NUMBER

DE-AC36-99-G010337

5b. GRANT NUMBER

5c. PROGRAM ELEMENT NUMBER

5d. PROJECT NUMBER

NREL/CP-500-37355

5e. TASK NUMBER

WER5 3108

5f. WORK UNIT NUMBER
7. PERFORMING ORGANIZATION NAME(S) AND ADDRESS(ES)

National Renewable Energy Laboratory

1617 Cole Blvd.

Golden, CO 80401-3393
8. PERFORMING ORGANIZATION REPORT NUMBER

NREL/CP-500-37355

9. SPONSORING/MONITORING AGENCY NAME(S) AND ADDRESS(ES)

10. SPONSOR/MONITOR'S ACRONYM(S) NREL

11. SPONSORING/MONITORING AGENCY REPORT NUMBER

12. DISTRIBUTION AVAILABILITY STATEMENT

National Technical Information Service

U.S. Department of Commerce

5285 Port Royal Road

Springfield, VA 22161

13. SUPPLEMENTARY NOTES

14. ABSTRACT (Maximum 200 Words)

Utility system operators and engineers now want a better understanding of the impacts of large wind farms on grid stability before the farms are interconnected to the grid. Utilities need wind farm electrical models and methods of analysis that will help them analyze potential problems of grid stability. Without the necessary tools and knowledge of the behavior of large wind power plants, utilities are reluctant to integrate more wind power into the grid. The dynamic models used in this paper were developed by Power Technologies Inc. (PTI), under subcontract from ERCOT. A three-phase fault on important buses will be tested, and the potential impact on wind farms will be investigated. Two methods, dynamic analysis and steady state analysis (Zbus prediction), will be used to predict the low voltage ride through capability of the wind farms. Comparison between the two methods will be presented.

15. SUBJECT TERMS

wind turbine; wind farm; wind energy; aggregation; power system; variable-speed generation; renewable energy; low voltage ride through

\begin{tabular}{|c|c|c|c|c|}
\hline 16. SECURITY & CLASSIFICATI & N OF: & 17. LIMITATION & 18. NUMBER \\
\hline $\begin{array}{l}\text { a. REPORT } \\
\text { Unclassified }\end{array}$ & $\begin{array}{l}\text { b. ABSTRACT } \\
\text { Unclassified }\end{array}$ & $\begin{array}{l}\text { c. THIS PAGE } \\
\text { Unclassified }\end{array}$ & $\begin{array}{c}\text { OF ABSTRACT } \\
\text { UL }\end{array}$ & \\
\hline
\end{tabular}

19a. NAME OF RESPONSIBLE PERSON

19b. TELEPHONE NUMBER (Include area code) 